\title{
COST ANALYSIS IN THE AUDIT OF SELECTED COMPANIES IN POLAND
}

\author{
Anna Mazurczak-Mąka \\ Cracow University of Economics, Cracow, Poland \\ e-mail: mazurcza@uek.krakow.pl
}

ORCID: 0000-0003-1723-5167

\author{
Monika Turek-Radwan \\ Cracow University of Economics, Cracow, Poland \\ e-mail: turekm@uek.krakow.pl
}

ORCID: 0000-0002-5166-7476

(C) 2019 Anna Mazurczak-Mąka, Monika Turek-Radwan

This is an open access article distributed under the Creative Commons Attribution-NonCommercial-NoDerivs license (http://creativecommons.org/licenses/by-nc-nd/3.0/)

DOI: 10.15611/fins.2019.1.03

JEL Classification: M41, M42, M40

\begin{abstract}
The aim of the article is to present the issues related to the work of auditors in the area of cost analysis as an element of the financial statement in an enterprise. Empirical studies were conducted on the basis of the financial statements published by selected companies listed on the NewConnect market in 2017, as well as the audit reports issued for those companies. The partial goals include the assessment of the percentage of certain types of opinions issued by independent auditors reviewing the financial statements of selected companies listed, as well as the identification of the areas regarding costs of activities, which are most often described in the explanations or qualified opinions in the research sample under analysis. The undertaken research are preliminary and in the future should be carried out on a larger research sample divided into industry sectors
\end{abstract}

Keywords: costs, financial statement analysis, financial review, listed companies.

\section{Introduction}

For many years, the issue of access to information has been crucial not only for investors but also for other groups of interested parties. In the context of economic uncertainties, sole access to information is no longer sufficient as it is crucial that the information itself is confirmed as reliable and credible. Reliable financial statements are fair reviews of the company for current and potential investors, as well as other external users, and reduce the asymmetry of information between the managing body and the external environment. 
The quality of the prepared financial statements "depends primarily on whether the accounting information created in the books is reliable" [Kutera et al. 2006, p. 21]. The audit of financial statements by an expert auditor ensures a high level of correctness of such a report; unfortunately, it does not guarantee the total elimination of all irregularities [Grabowska-Kaczmarczyk 2016, p. 29].

M. Ślezbak and K. Ślezbak [2014] claim that "from the point of view of the third parties, auditing is predominantly about the confirmation of the audited entities' financial data reliability by an independent professional, which promotes the growth of the safety of the economic and legal turnover in the entity".

Manipulation of data included in the financial report is usually done to improve the image of the company, to achieve financial gain or to avoid the responsibility by persons associated with the audited entity [Wąsowski 2010, p. 8].

The many scandals of recent years that shook financial markets caused a significant decline in the level of trust in regard to information presented by companies in financial statements. Due to the above, financial audit is a fundamental stage of preparing the final version of financial statements.

In practice, the manifestation of the corrective function of auditing financial statements is that expert auditors who encounter various serious errors and irregularities during their work usually propose to correct them. If the introduction of these corrections is possible and the board of the audited entity agrees, the financial statement should be corrected [Andrzejewski 2012, p. 11].

The correctness and reliability of the financial information disclosed by the entities depend primarily on the efficiency of the financial reporting and accounting bodies, the reporting systems of the entity and the internal control system. One of the tools to increase confidence in the financial statements is their examination by external and independent expert auditors.

Public companies should prepare reliable financial reports and disclose information in a legible and unambiguous way. The reliability of the accounting and reporting of stock market listed companies is controlled by an expert auditor and the examination of financial statements of issuers is obligatory [Turek-Radwan, Mazurczak 2012, p. 119].

\section{The essence and function of a financial audit}

Auditing an entity's financial statement by an independent auditor can either be obligatory pursuant to article 64 of The Accounting Act [Act on Accounting... 1994] or be an effect of a voluntary decision of an entity/company. An audit by an independent auditor increases the assurance that a financial statement has been prepared correctly and fairly, and it does not contain errors impacting material aspects, which would disqualify it as a source of information for the management and other users (including third-party users) such as owners, banks, tax authorities, and investors [Kalandyk et al. 2015, p. 544]. 
It should be however underlined that a positive opinion by an auditor does not absolutely ensure that a financial statement is absolutely free of any errors, as the methods used by auditors are designed to identify material faults that would impact on the evaluation of the statement as a whole [Marzec, Śliwa 2012, p. 59].

The opinion of the auditor is issued in regard to the final version of the financial statement. Before the publication of such a final version, the auditor discloses the identified irregularities to the management and proposes corrections. Only after the proposed corrections are introduced or a refusal of correction is made, a final version of a financial statement is prepared, and the auditor issues his/her opinion in regard to such a final version. Among the functions of a financial audit, the corrective function is one the most important [Andrzejewski 2012].

A financial audit, through the application of its procedures, methods and techniques, also fulfills the following functions (cf. [Hołda, Pociecha 2005]):

1) control,

2) information,

3) validation.

The functions of control and information are convergent with the functions of modern accounting. It should be underlined that the auditing of financial statements per se realizes the control functions of accounting. The control function in the financial audit system mainly consists in the verification by the auditor of accounting records and other documents which were the basis of the financial statement.

The information function consists in the transfer of an amount of information in particular to the mandator via the use of opinions, statements and other documents issued by the auditor (as the external users do not have access to the information identified in the course of an audit, for example the table of corrections). This aspect regards the passing of information internally to the entity. It must be however stated that the fact that an opinion is issued by the auditor (even though the contents of the opinion does not contain all of the information identified during the audit as stated above) is a confirmation of the correctness of the financial statement or an identification of issues that were not remedied during the audit process [Krzywda 2005, p. 18]. Due to that fact the external effect of the information function is also achieved in a certain scope.

The above considerations are completed by the validation function, which consists in the confirmation of the correctness and fairness of financial statement or the indication of its faults, which happen via the auditor's opinion.

\section{Cost analysis in economic entities by the expert auditor}

Costs and income are two elements of the financial result which are inherently connected in particular by the matching rule. Costs generally arise due to activities aimed at achieving a positive financial result. Costs are one of the main economic 
categories used in accounting which exist in all commercial entities. No commercial entity can fulfill its activities without incurring costs.

One of the main and fundamental characteristic of costs is their purposefulness. The incurring of costs must be connected with achieving an effect. This is important to assign costs unequivocally to a relevant period (e.g. a year, a quarter, a month). It is the requirement of the matching rule in regard to linking the costs with the income achieved which enables to establish the financial result in a proper manner. In a situation when costs arise that are connected with more than one accounting period, inter-period settlements must be made.

Costs are important as manner of reviewing the effectiveness of the entity's operations and are the basis of reference for the income achieved. From the income point of view, it is important for the costs to be as low as possible and due to that fact the risk occurs that the costs will be underreported leading to a better financial result. The opposite situation can also arise. All the material misstatements in the presentation and a proper valuation of costs should be reflected in the financial audit.

The purpose of the audit of financial statements [Micherda 2010, pp. 193-228] is issuing an opinion on their compliance with the applied accounting policies and determining whether the financial and material situation of the audited entity has been presented in a fair and clear manner [Act on Accounting... 1994]. Issues concerning the need to ensure an appropriate level of quality and reliability of the financial statements are reflected in the national and international regulations. International regulations are primarily adapted to the changing conditions and needs of the environment [Grabowska-Kaczmarczyk 2016, p. 29]. In accordance with the International Standards on Auditing, the purpose of the expert auditor is recognizing and estimating the risk of significant irregularities caused by fraud or errors at the level of the financial statements and the individual components of this report [National Standard on Auditing 315].

During the performance of the audit of costs by the auditing company, costs directly related to the economic activity are taken into consideration, along with other operating costs and financial costs. Most of these elements emerge in connection with carrying out of the operations by the entity in terms of trade, manufacture or services. The costs incurred can also be the result of transactions such as the sales of securities or assets of the entity or elements thereof, the clearance of the accounts payable in foreign currencies, shares and payment of liabilities using bills of exchange [Krzywda, Szafraniec 2012, pp. 447-457].

The Act on Accounting defines costs and losses as a firm's decrease in economic benefits in the reporting period, of a reliably determined value, in the form of the decreased value of assets or the increased value of liabilities and provisions which will lead to decreasing equity or increasing shortage of equity in other ways than the withdrawal of funds by shareholders or owners [Act on Accounting... 1994, art. 3.1, item 31]. 
The aim of cost auditing is to determine whether the costs were actually incurred and properly recorded in the appropriate positions and the appropriate reporting period [Krzywda, Szafraniec 2012, p. 455].

Table 1. Auditing of costs directly related to the operating activities of an economic entity

\begin{tabular}{|c|c|c|}
\hline dit & nce & dures \\
\hline $\begin{array}{l}\text { 1. Evidence of costs } \\
\text { directly related to the ope- } \\
\text { rating activities of an eco- } \\
\text { nomic entity } \\
\text { 2. Evidence of comple- } \\
\text { teness of data recorded in } \\
\text { the books of accounts } \\
\text { 3. Evidence of the cor- } \\
\text { rectness of reporting costs } \\
\text { directly related to the ope- } \\
\text { rating activities of an eco- } \\
\text { nomic entity } \\
\text { 4. Confirmation of the } \\
\text { accuracy of measurement } \\
\text { methods } \\
\text { 5. Confirmation of the } \\
\text { accounting of cost ele- } \\
\text { ments for example wages, } \\
\text { social security contribu- } \\
\text { tions and taxes as part of } \\
\text { the costs } \\
6 \text {. Classifying costs as } \\
\text { deductible and non-deduc- } \\
\text { tible expenses } \\
7 \text {. The accuracy of the } \\
\text { used calculation, the clas- } \\
\text { sification of indirect costs } \\
\text { into fixed, and variables, } \\
\text { and the fixed costs into } \\
\text { reasonable and unreaso- } \\
\text { nable, and the valuation of } \\
\text { work in progress } \\
8 \text {. The proper distinc- } \\
\text { tion in time and reference } \\
\text { to revenue from sales and } \\
\text { the costs of non-completed } \\
\text { long-term services }\end{array}$ & $\begin{array}{l}\text { 1. Books of account } \\
\text { 2. Synthetic and } \\
\text { analytical books } \\
\text { 3. Source evidence } \\
\text { 4. Unit cost calcula- } \\
\text { tion } \\
\text { 5. Stocktaking docu- } \\
\text { ments } \\
\text { 6. Documentation } \\
\text { of the findings of the } \\
\text { estimated costs of non- } \\
\text {-completed long-term } \\
\text { services } \\
\text { 7. Profit and loss ac- } \\
\text { count } \\
\text { 8. Balance sheet } \\
\text { 9. Introduction to } \\
\text { the financial statements } \\
\text { and additional informa- } \\
\text { tion and explanations }\end{array}$ & $\begin{array}{l}\text { 1. Analytical review: } \\
\text { - comparison of costs in the various accounts } \\
\text { for the current year with the last year } \\
\text { - identification of significant changes, poin- } \\
\text { ting out cost items or items that do not exist } \\
\text { 2. Verification of compliance of the analyti- } \\
\text { cal value with the synthetic value } \\
\text { 3. Selection of the test sample to examine } \\
\text { the completeness of costs in individual systems } \\
\text { and their correct classification by comparison } \\
\text { with source evidence } \\
\text { 4. Conducting detailed tests for atypical co- } \\
\text { sts or new cost elements, taking into account } \\
\text { the desirability of incurring them } \\
\text { 5. Checking the possibility of dividing indi- } \\
\text { rect costs using the production capacity } \\
\text { 6. Confirmation of the reliability of the in- } \\
\text { ventory in progress } \\
\text { 7. Use of detailed tests to check the correct- } \\
\text { ness of depreciation, remuneration, social insu- } \\
\text { rance contributions, taxes and fees, and delimi- } \\
\text { tation of costs over time } \\
\text { 8. Checking the completeness of costs by } \\
\text { random examination of cost documents for the } \\
\text { next financial year, for example on energy costs } \\
\text { or telecommunications services } \\
\text { 9. Comparison of cost records and source } \\
\text { documents for costs not recognized by tax re- } \\
\text { gulations } \\
\text { 10. Testing the correctness of determining } \\
\text { the cost of manufacturing products sold by } \\
\text { checking the determination of production costs } \\
\text { of products accepted into the warehouse and } \\
\text { products sold comparing the evidence of the } \\
\text { warehouse receipts, evidence of delivery and } \\
\text { sales invoices } \\
\text { 11. Comparison of the findings with the pre- } \\
\text { sentation of the profit and loss account and in } \\
\text { the additional information and explanations }\end{array}$ \\
\hline
\end{tabular}

Source: own study based on [Krzywda, Szafraniec 2012, pp. 451-453]. 
Costs directly related to the operating activities of an economic unit are a special area of interest for the expert auditor during their work. The basic costs of operations have a significant impact on the size of the profit and the amount of income tax. The adopted method of cost accounting has a significant impact on the auditing procedures, the settlement and relating them to the revenue from the economic operation [Gabrusewicz 2014, p. 217].

In enterprises from the trade sector, the basic cost item is the value of goods and materials sold at purchase or acquisition prices. When examining this type of positions, the auditor should first check the method of recording the incoming and outgoing goods, the method of identifying variations from the registered prices and their impact on the sales results [Gabrusewicz 2014, p. 218].

Table 2. Auditing of other operating costs in an economic entity

\begin{tabular}{|c|c|c|}
\hline Aim of audit & Evidence & Auditing procedures \\
\hline $\begin{array}{l}\text { 1. Confirmation of } \\
\text { other operating costs } \\
\text { 2. Evidence of comple- } \\
\text { teness of data recorded } \\
\text { in the books of account } \\
\text { 3. Confirmation of the } \\
\text { correctness of time } \\
\text { periods } \\
\text { 4. Confirmation of the } \\
\text { correctness of docu- } \\
\text { menting the items of } \\
\text { other operating costs } \\
\text { 5. Confirmation of the } \\
\text { accuracy of measure- } \\
\text { ment methods } \\
\text { 6. Confirmation of } \\
\text { the correctness of the } \\
\text { presentation of other } \\
\text { operating expenses in } \\
\text { the statement of profit } \\
\text { and loss and in the } \\
\text { additional information } \\
\text { and explanations }\end{array}$ & $\begin{array}{l}\text { 1. Books of account } \\
\text { 2. Synthetic and analy- } \\
\text { tical books } \\
\text { 3. Source evidence, } \\
\text { e.g. VAT invoices, cor- } \\
\text { rective VAT invoices, } \\
\text { documents verifying } \\
\text { settlements, decisions } \\
\text { of the state admini- } \\
\text { stration and the local } \\
\text { government, decisions } \\
\text { of tax authorities, agre- } \\
\text { ements with contrac- } \\
\text { tors regarding penal- } \\
\text { ties, court judgments, } \\
\text { evidence of court and } \\
\text { enforcement costs, do- } \\
\text { cuments authenticating } \\
\text { impairment write-offs } \\
\text { of property } \\
\text { 4. Profit and loss } \\
\text { account } \\
5 . \text { Introduction to the } \\
\text { financial statements } \\
\text { and additional informa- } \\
\text { tion and explanations }\end{array}$ & $\begin{array}{l}\text { 1. Analytical review: } \\
\text { - comparison of individual items by title in other } \\
\text { operating expenses for the current year to the } \\
\text { previous year, } \\
\text { - the disclosure of material changes, indicating } \\
\text { new items } \\
\text { 2. Analysis of compliance of analytical records } \\
\text { with synthetic ones } \\
\text { 3. The detailed study of transactions by: } \\
\text { - comparison of records with source evidence to } \\
\text { confirm their occurrence, completeness, classi- } \\
\text { fication and correctness of the valuation, analy- } \\
\text { sis of the correctness of the documentation, } \\
\text { - checking the correctness of qualifying taxable } \\
\text { costs by analyzing and comparing them with in- } \\
\text { come tax regulations, } \\
\text { - checking the separation of differences in the } \\
\text { scope of the taxation of temporary differences } \\
\text { from the point of view of determining deferred } \\
\text { tax assets or deferred tax liability, } \\
\text { - linking the revaluation of non-financial assets to } \\
\text { the review of impairment allowances for assets } \\
\text { and the examination of recognized provisions } \\
\text { recognized in the balance sheet liabilities } \\
\text { 4. Establishing whether the individual costs and } \\
\text { gains from the disposal of fixed assets are correct } \\
\text { 5. Comparing the findings by the expert auditor } \\
\text { related to the disclosure or other operating costs } \\
\text { in the profit and loss account along with additio- } \\
\text { nal information and explanations }\end{array}$ \\
\hline
\end{tabular}

Source: own study based on [Krzywda, Szafraniec 2012, pp. 454-455]. 
Table 3. Financial costs auditing in an economic entity

\begin{tabular}{|c|c|c|}
\hline Aim of audit & Evidence & Auditing procedures \\
\hline $\begin{array}{l}\text { 1. Evidence of finan- } \\
\text { cial costs } \\
\text { 2. Evidence of comple- } \\
\text { teness of data recorded } \\
\text { in the books of account } \\
\text { 3. Evidence of the } \\
\text { correctness of cost } \\
\text { documentation } \\
\text { 4. Confirmation of the } \\
\text { accuracy of measure- } \\
\text { ment methods } \\
\text { 5. Confirmation of the } \\
\text { correctness of disclo- } \\
\text { sure of differences in } \\
\text { financial costs in terms } \\
\text { of balance and tax law } \\
6 \text {. Confirmation of the } \\
\text { correctness of the pre- } \\
\text { sentation of the profit } \\
\text { and loss account and } \\
\text { the additional informa- } \\
\text { tion and explanations }\end{array}$ & \begin{tabular}{|l|} 
1. Books of account \\
2. Synthetic and analy- \\
tical accounts \\
3. Source evidence, \\
e.g. sales contracts, \\
bank statements, sales \\
of claims invoices, \\
loan agreements, \\
shareholder meeting \\
resolutions, eviden- \\
ce of payment, cash \\
receipts, internal do- \\
cuments regarding the \\
settlement of exchange \\
differences, interest \\
accrual, decisions of \\
administrative and \\
tax authorities, court \\
judgments \\
4. Profit and loss \\
account \\
5. Introduction to the \\
financial statements \\
and additional informa- \\
tion and explanations
\end{tabular} & $\begin{array}{l}\text { 1. Analytical review: } \\
\text { - comparing the various titles of financial costs in } \\
\text { the current year to the previous year, } \\
\text { - disclosure of material changes, indicating if the- } \\
\text { re are new positions } \\
\text { 2. A detailed analysis of transactions with source } \\
\text { documentation in terms of the completeness, the } \\
\text { correctness or classification and accuracy of the } \\
\text { valuation of: } \\
\text { - interest on loans from credit agreements, loan } \\
\text { agreements, interest calculation, withholding } \\
\text { and payment documents, } \\
\text { - dividends and shares in profits with the evidence } \\
\text { of receipt, } \\
\text { - debt securities' deadlines, dates of their trading } \\
\text { and the accuracy of the calculation of interest, } \\
\text { - liabilities in the amount payable, } \\
\text { - liabilities in foreign currency and determining } \\
\text { exchange differences in plus or minus as of the } \\
\text { sheet date, } \\
\text { - foreign currency during the financial year and } \\
\text { the balance day, } \\
\text { - the cost of acquisition of securities along with } \\
\text { comparing them with source documentation, } \\
\text { - financial investment by comparing the purchase } \\
\text { prices with market prices or otherwise determi- } \\
\text { ned fair values } \\
\text { 3. Comparison of the findings of the expert in the } \\
\text { disclosure and presentation of financial expenses } \\
\text { in the profit and loss account along with addition- } \\
\text { al information and explanations }\end{array}$ \\
\hline
\end{tabular}

Source: own study based on [Krzywda, Szafraniec 2012, p. 455-457].

The remaining operating costs are the costs directly related to the economic operation of the entity, and in particular the costs arising from:

- social activities,

- the sale of fixed assets, fixed assets under construction, intangible assets, property and intangible assets credited to investment,

- the maintenance of property and intangible assets credited to investment, including upgrading the value of these investments or re-classifying them as fixed assets and intangible assets if the valuation of the investments assumed market price or another fair value,

- writing off receivables and liabilities expired, de-committed, or non-collectable except for public law receivables and liabilities which do not load the costs, 
- the creation and reversal of provisions, except for the provisions related to the financial operations,

- the deductions updating of assets value and its adjustments, except deductions aggravating the financial costs,

- compensations and penalties,

- random events [Act on Accounting... 1994, art. 3.1, item 32].

Numerous audits conducted in the field of auditing financial statements clearly indicate that cost-related frauds and errors detected during the audit by the audit firm are often connected with the manipulation of estimates, which are write - downs of receivables and inventory or the improper creation of provisions and reserves [Lew 2015, p. 311]. During the annual audit of the financial statements in the economic entity, the auditor, observing the occurrence of such an event, should review the documents provided by the entity by comparing the source documents with the entries presented in the profit and loss account, or by analyzing revenues and costs at the turn of the financial year [Lew 2015, p. 311].

If the auditor detects fraud or suspected fraud, they should contact the leadership of the entity or a person authorized by the audited company to represent it as soon as possible. In a situation when such a procedure would be insufficient, they should contact the leadership of the highest level. If, despite having taken these steps, based on their professional judgment and skepticism, while the auditor decides that the explanations they received are insufficient, they should inform the appropriate authorities for whom they are conducting the audit of the financial statement. In accordance with the law in force in Poland some fraud related to costs can become economic offences prosecuted by the state under criminal law. Should such a situation occur, it is the duty of the auditor to inform the competent authority of the prosecution of such a crime [Lew 2015, p. 310].

\section{Cost analysis in economic practice as shown by the companies listed on the NewConnect alternative market}

The main purpose of this paper is the analysis of the types of opinions issued by auditors reviewing companies listed on the NewConnect alternative market and to identify the important information included in such opinions disclosed by companies in regard to the costs of activities. This purpose enables to identify the research goals which include:

1) assessing the percentage of certain types of opinions issued by independent auditors reviewing the financial statements of selected companies listed on the NewConnect market in 2017;

2) identifying the areas regarding costs of activities, which are most often described in the explanations or qualified opinions in the research sample under analysis. 
In order to achieve the main purpose and the partial goals, 11 opinions issued by independent auditors, regarding companies operating in sectors such as computers and electronics, electrical and electronical equipment, IT equipment, and consumer electronics, were analyzed. The detailed analysis comprised of the audit's opinion of only two companies, because in the case of the other nine companies the auditor issued unqualified opinions which means that the financial statements of those companies were free from material misstatements.

Table 4. Types of opinions issued by independent auditors in regard to financial statements of selected companies in 2017

\begin{tabular}{|l|l|}
\hline \multicolumn{1}{|c|}{ Company name } & \multicolumn{1}{c|}{ Type of opinion } \\
\hline ARTP S.A. & Unqualified opinion \\
\hline BDF S.A. & Disclaimer opinion \\
\hline BIZTECH S.A. & Unqualified opinion \\
\hline BPX S.A. & Unqualified opinion \\
\hline Cyfrowe Centrum Serwisowe S.A. & Unqualified opinion with additional explanations \\
\hline Digital Avenue S.A. & Unqualified opinion \\
\hline GOVENA S.A. & Unqualified opinion \\
\hline IMAGIS S.A. & Qualified opinion \\
\hline LUKARDI S.A. & Unqualified opinion with additional explanations \\
\hline MEGASONIC S.A. & Unqualified opinion \\
\hline MODECOM S.A. & Unqualified opinion \\
\hline
\end{tabular}

Source: own elaboration on the basis of the opinions issued by auditors in regard to the financial statements of selected companies listed on the NewConnect market in 2017.

As indicated by the independent auditor auditing the financial statement of the company BDF S.A., the issuing of an opinion was not possible in a situation when it was impossible to obtain adequate and sufficient audit evidence. The auditor underlined that the company does not operate and does not have any sources of funding. In the year in question (2017), the company also made write-downs in regard to the value of investments in subsidiary companies amounting to $157.9 \mathrm{~m}$. PLN. In the introduction to the financial statement the management board indicated the risk for the continuation of activities due to short-term liabilities amounting to $14.7 \mathrm{~m}$. PLN. The auditor was not presented with any credible remedial procedure including the acquiring of funding sources.

In regard to IMAGIS S.A., the auditor indicated that the financial statement in the long-term investments positions showed the value of an investment real estate amounting to 3974400 net PLN including a gross value of 7005720 PLN and a write-down of 3031320 PLN. The management board of the company did not provide the auditor with a fair value evaluation of the asset in question current as of $31^{\text {st }}$ December 2017. The report on the evaluation of the real estate in question lost its validity in March 2017. Due to the above the auditor was not able to confirm 
the evaluation of the real estate and to address the issue of increasing the writedown (impacting costs) or its dissolution. In the case described above, yet again the main issue touches on the estimated values impacting on the asset valuation and potentially on the cost or income position in the financial statement.

Estimated values within the costs of an entity are the result of:

- adopting the valuation assumptions in the accounting policy e.g. the estimated time of use of the fixed assets and the resulting deprecation rate;

- using estimation categories for the valuation of assets and liabilities (e.g. fair value, adjusted purchase price, market price) - the changes in valuation may impact the costs of the entity;

- making write-downs due to the loss of value - usually the loss of value will impact the costs of the entity.

From the auditing perspective, the estimated values are among the positions burdened by a potentially significant risk of a material distortion [Pfaff 2016, pp. 96-97].

It should be underlined that within the research sample, $81 \%$ of the opinions were unqualified opinions. The authors are aware that this result could be different in cases when more companies would be taken into account and can be dependent on the specific branch. Further research should be based on more companies, both listed on NewConnect as well as on the Warsaw Stock Exchange, and this is one of the possible directions for the authors' research. Other researchers found that almost $90 \%$ of all the opinions are unqualified ones. J. Pfaff, whose research was based on a sample of 223 companies, established that in $89 \%$ of cases auditors issued an unqualified opinion [Pfaff 2007, pp. 186-187]. Similar results were obtained by M. Andrzejewski and A. Mazurczak in a research sample consisting of 660 opinions and reports from 132 companies in 2005-2009, who observed that more than $88.5 \%$ of opinions are unqualified opinions [Andrzejewski, Mazurczak 2011, pp. 223-248].

As shown above in the auditor's justification, a common problem in regard to financial statements are estimated values. In the entities under review as described above, the area of costs in question were the estimated values in the context of write-downs. Estimated values can be problematic as their valuation is based on many assumptions which may eventually change and influence the values of the financial results in an unexpected direction. In the case of an increase in the scale of the entity's use of estimated valuation and fair value, the degree of testing difficulty increases [Ettredge, Xu, Yi 2014, p. 33]. The question of assessing estimated values is considered extremely current and at the same time complicated. Due to the limited value of information disclosures regarding the estimation of the values presented in the financial statements, the role of the statutory auditor should be considered as significant [Zieniuk 2018, p. 121]. 


\section{Conclusion}

Detected irregularities and fraud emerging within the scope of the financial statement audited prevent potential stakeholders from having full confidence in the information provided by companies.

The auditor inspecting a financial statement in accordance with the applicable national standards of financial auditing has the knowledge and economic practice to identify the symptoms of distortion of the report as a result of financial fraud. The task of the audit firm conducting the auditing in an enterprise does not focus only on the search for possible fraud, errors or infringements of the law; however, professional skepticism should facilitate the identification and proper evaluation of the probability of committing such acts in the company.

The empirical studies which were conducted on the basis of the financial statements published by 11 selected companies listed on the NewConnect market in 2017 , as well as the audit reports issued for those companies showed that the majority of opinions (81\%) are unqualified. The authors are aware that this result could be different when more companies would be taken into account and this should be taken into account in the development of future research. The results of the research have confirmed that the vast majority of the financial statements misstatements in the area of costs concern estimated values. Therefore, the authors believe that there is a constant need to improve both the proper valuation and disclosure made by companies in their financial statements as well as the methodology of the audit in assessing estimated values.

\section{Bibliography}

Act on Accounting of 29 September 1994 as amended (Journal of Laws [Dz.U.] 2017, item 1047).

Andrzejewski M., 2012, Korygująca funkcja rewizji finansowej w systemie rachunkowości, Wydawnictwo Uniwersytetu Ekonomicznego w Krakowie, Kraków.

Ettredge M.L., Xu Y., Yi H.S., 2014, Fair value measurements and audit fees: Evidence from the banking industry, Auditing: A Journal of Practice \& Theory, vol. 33, no. 3, August.

Gabrusewicz P., 2014, Etapy audytu sprawozdań finansowych, [in:] Gabrusewicz W. (ed.), Audyt sprawozdań finansowych, teoria i praktyka, Polskie Wydawnictwo Ekonomiczne S.A., Warszawa.

Grabowska-Kaczmarczyk E., 2016, Ewolucja rewizji finansowej i jej wptyw na jakość procesu badania sprawozdania finansowego, [in:] Andrzejewski M. (ed.), Ewolucja sprawozdawczości i rewizji finansowej w systemie rachunkowości, Difin, Warszawa.

Hołda A., Pociecha J., 2005, Rewizja finansowa, Wydawnictwo Akademii Ekonomicznej w Krakowie, Kraków.

Kalandyk N., Kalandyk P., Rymkiewicz B., 2015, Zmiana wybranych pozycji sprawozdania finansowego w wyniku jego atestacji na przykładzie spółek notowanych na NewConnect, Zeszyty Naukowe Uniwersytetu Szczecińskiego nr 873, Finanse, Rynki Finansowe, Ubezpieczenia, nr 77.

Krajowy Standard Rewizji Finansowej 1, 2010, PIBR, Warszawa. 
Krzywda D., 2005, Istota, cel i podstawy prawne rewizji sprawozdań finansowych, [in:] Krzywda D. (ed.), Rewizja sprawozdań finansowych, SKwP, Warszawa.

Krzywda D. (ed.), 2012, Rewizja sprawozdań finansowych, Difin, Warszawa.

Krzywda D., Szafraniec J., 2012, Badanie poszczególnych części sprawozdania finansowego, [in:] Krzywda D. (ed.), Rewizja sprawozdań finansowych, SKwP, Warszawa.

Kutera M., Hołda A., Surdykowska S.T., 2006, Oszustwa księgowe. Teoria i praktyka, Difin, Warszawa.

Lew A., 2015, Badanie przez biegłego rewidenta przychodów i kosztów jako elementów podatnych na oszustwa księgowe, Prace Naukowe Uniwersytetu Ekonomicznego we Wrocławiu nr 399.

Marzec J., Śliwa J., 2012, Audyt finansowy w jednostkach gospodarczych - teoria i praktyka, Wydawnictwo Naukowe Wydziału Zarządzania UW, Warszawa.

Micherda B., 2010, Cel i uwarunkowania badania sprawozdania finansowego w świetle sytuacji kryzysowej, [in:] Andrzejewski M. (ed.), Rachunkowość wobec kryzysu gospodarczego, Difin, Warszawa.

National Standards on Auditing 315, in the wording of ISA, PIBR, Warsaw, 5.03.2018.

Pfaff J., 2016, Wartości szacunkowe w kosztach przedsiębiorstwa oraz procedury ich badania zgodnie z Międzynarodowymi Standardami Rewizji Finansowej, Zeszyty Naukowe Politechniki Częstochowskiej, Zarządzanie, nr 23, t. 2.

Ślezbak M., Ślezbak K., 2014, Spodziewane zmiany ustawy o rachunkowości a obligatoryjne badania sprawozdań finansowych, Rachunkowość, no. 8.

Turek-Radwan M., Mazurczak A., 2012, Rola analizy finansowej w raportach biegłego rewidenta, [in:] Stabilność systemu finansowego warunkiem rozwoju gospodarczego, Wydawnictwo Wyższej Szkoły Finansów i Prawa, Bielsko-Biała.

Wąsowski W., 2010, Kreatywna rachunkowość. Fatszowanie sprawozdań finansowych, wyd. 2 rozszerzone, Difin, Warszawa.

Zieniuk P., 2018, Wartości szacunkowe w teorii rachunkowości i w praktyce spółek giełdowych, Difin, Warszawa.

\section{ROLA ANALIZY FINANSOWEJ W RAPORTACH BIEGLEGO REWIDENTA}

Streszczenie: Celem artykułu jest przedstawienie zagadnień związanych z pracą biegłego rewidenta, dotyczącyh analizy kosztów jako elementu sprawozdania finansowego w przedsiębiorstwie. Badania empiryczne przeprowadzono na podstawie sprawozdań finansowych wybranych spółek notowanych na rynku NewConnect, a także opinii biegłych rewidentów wydanych odnośnie do opublikowanych sprawozdań. W toku prowadzonych badań ustalono strukturę poszczególnych rodzajów opinii wydawanych przez niezależnych biegłych rewidentów, a także zidentyfikowano obszary w zakresie kosztów prowadzonej działalności, co do których biegli rewidenci zgłaszali zastrzeżenie. Jak wynika z przeprowadzonych badań, większość opinii biegłych rewidentów nie zawiera zastrzeżeń, a zastrzeżenia z zakresu kosztów dotyczą najczęściej wartości szacunkowych.Przeprowadzone analizy mają charakter wstępny. Dalsze badania powinny objąć większą próbę badawczą oraz dotyczyć analizy zastrzeżeń w podziale branżowym.

Słowa kluczowe: analiza finansowa, raport biegłego rewidenta, spółki giełdowe. 